\title{
Flipped Classroom: Edmodo-based Economic Learning
}

\author{
Suranto*, Harsono, Intan Putri Hapsari, Rinika Windra Puspita \\ Faculty of Teacher Training and Education, Universitas Muhammadiyah Surakarta, Indonesia
}

Received June 12, 2020; Revised August 14, 2020; Accepted August 28, 2020

\section{Cite This Paper in the following Citation Styles}

(a): [1] Suranto, Harsono, Intan Putri Hapsari, Rinika Windra Puspita, "Flipped Classroom: Edmodo-based Economic Learning," Universal Journal of Educational Research, Vol. 8, No. 10, pp. 4507-4513, 2020. DOI: 10.13189/ujer.2020.081018.

(b): Suranto, Harsono, Intan Putri Hapsari, Rinika Windra Puspita (2020). Flipped Classroom: Edmodo-based Economic Learning. Universal Journal of Educational Research, 8(10), 4507-4513. DOI: 10.13189/ujer.2020.081018.

Copyright $\bigcirc 2020$ by authors, all rights reserved. Authors agree that this article remains permanently open access under the terms of the Creative Commons Attribution License 4.0 International License

\begin{abstract}
This study aimed to determine the effectiveness of using Edmodo-based Flipped Classroom learning model in improving student learning outcomes in economic subjects at the high school level. The research method used was quantitative with quasi-experimental research. The research design used pretest-posttest control group design. The population in this study was all students of class X Social Sciences in senior high school at SMA Negeri 3 Sukoharjo, Central Java, Indonesia. Sampling was done by probability sampling with class X Social Sciences 3 as the control class and class X Social Sciences 4 as the experimental class. Data collection techniques used were tests and observation. The researchers used independent sample t-test to analyze the data. The results showed that there were differences in student learning outcomes in the control class and in the experimental class. The difference can be seen from the average post-test value of the control class 62.43 , while the average post-test value of the experimental class was 70.00. The t-test results also showed the value of $t$ count 3.633 was $>$ than $t$ table 1.955 , and the significance value was $0.001<0.05$. Our evidence suggested that economic learning using Edmodo-based Flipped Classroom learning models could more effectively improve student learning outcomes compared to learning with conventional systems.
\end{abstract}

Keywords Economic Learning, Flipped Classroom, Edmodo, Learning Outcomes

\section{Introduction}

Sustainability of the learning process and good learning will be achieved with the support of all components of education, especially learning models. In the era of modern technology, the creation of an internet-based learning model is an effort to improve and develop the quality of education. Educational changes have begun to develop slowly, but the development of computer and network technology over the past decade offers new education and unique ways to connect with their students, to inform, collaborate, and assess the learning process [1].

The development of information and communication technology has an enormous impact on human life, especially in the field of education. In ancient times, the students got sources of learning merely from teachers who taught in the class and from books, but not for now. Today we live in an age of globalization or what is commonly called modernization, so that it encourages information and communication technology to experience very rapid development. Modernization is a transformation of the situation from least developed into a better direction for the survival of society. An example of the development of information and communication technology in this modern era is the rise of the internet.

The development of information and communication technology has an enormous impact on human life, especially in the field of education. Thus, student learning time is not only limited in the class, for that the teachers must take advantage of this situation in order to bring a positive impact on students and on education. For adolescents, especially middle and high school students, internet is not strange, especially for teenagers in urban areas. It is because they are included in the category of generation $\mathrm{Z}$ who are very familiar with the use of the internet. Based on the results of a survey conducted by the Indonesian Internet Service Providers Association (APJII), 
$16.68 \%$ of Indonesia's population or a total of 23.9 million of 143.26 million internet users in Indonesia were teenagers aged 13-18 years [2]. This age is the age of junior high school students and senior high school students. This situation can be utilized by teachers to make learning models more effective and efficient.

Based on the results of preliminary observations in the class X Social Sciences high school students in Indonesia about the learning model of economics, when going to take lessons, most students did not know in advance what material would be discussed during the meeting. So it makes students unable to do any preparation before the implementation of learning. In reality, today, there are many problems in education encountered during the learning process [3]. One of problems found in the learning process was the lack of students' activity in the learning process in the classroom so that the learning process was only teacher oriented. Monotonous learning model also made students less motivated to learn. Most learning patterns were still conventional. By paying attention to these problems, the Flipped Classroom learning model can be one solution to the existing problems. The Flipped Classroom learning model is one of student-centered learning models to improve learning effectiveness. The basic concept of Flipped Classroom is that Students do at home everything that they do in the classroom in traditional learning, and moreover, students do all homework in the classroom that they do at home in traditional learning [4]. But some opinions from education experts about Flipped Classroom vary. Some educators consider the Flipped Classroom model to be the future standard of educational techniques [5]. Educators say that applying the Flipped Classroom learning model increases flexibility in implementing the learning process, improves student attitudes, and results in better exam grades [6].

The Flipped Classroom learning model has been recognized by educators as an innovative learning model and used as an effective learning approach [6]. The use of Flipped Classroom has the potential to become an effective and useful educational method. Replacing conventional learning in the classroom with the provision of video learning that is observed outside the classroom allows more time in the classroom to be used for active learning. Active learning can include discussion activities, problem solving, and group learning [5]. The use of time in this class can create a collaborative and constructivist classroom environment [7]. Constructivists are generative learning, which is the act of creating a meaning from what is learned. Constructivism learning occurs when students gain knowledge through direct personal experience such as activities, groups, and discussions [8].

This Flipped Classroom learning model is an active learning that involves students to learn effectively. Active learning will produce better value than passive learning. As curriculum requirements increase, teachers are pressured to utilize learning more efficiently [8]. The Flipped Classroom learning method has been proposed as a teaching method that can improve student learning by removing knowledge transmission from online classroom environments so that it allows more time to carry out learning [9]. With this Flipped Classroom Method, students can get the most out of the learning process by spending it using a more practical application. Research on the Flipped Classroom learning model in higher education and the results of a more detailed investigation of students' perceptions of its use are still at an early stage and the need for further research still needs to be highlighted [10]. In fact, the Flipped Classroom learning model resembles the learning design proposed by Morrison, Ross, Kalman, and Kemp because the instructor plays many roles, including content experts, instructional designers, and media developers [11].

In recent years the Flipped Classroom learning model has become an instructional development model in educational technology, especially in terms of technology related to higher education [12]. A learning model such as Flipped Classroom indeed needs to be applied in higher education, because this provides many benefits and convenience in carrying out the learning process. The Flipped Classroom Strategy also has some limitations in its application [13]. First, the video quality might be very bad. Second, the possibility of students seeing video learning in online classrooms is not effective because students can only see video learning while listening to music or playing other applications. Third, students do not watch or understand videos because they are not quite ready for face-to-face activities. The application of the Flipped Classroom learning model implicitly involves the use of technology to conduct learning outside the classroom, such as requiring students to watch videos or podcasts made by teachers, then using other multimedia materials, and online interactions [11].

In using the Flipped Classroom learning model, media are needed to create online classes. Flipped Classroom is a strategy that can be given by educators by minimizing the amount of direct instruction in their teaching practices while maximizing interaction with each other [14]. This strategy utilizes technology that provides extras that support learning material for students that can be accessed online. Online learning media with complete features and easy to operate functions include Edmodo. Edmodo is a private social network aimed at teachers and students to support online learning created [15]. Edmodo is a free and secure educational network that is used to provide learning in a simple way for teachers to create and manage online class communities and allows students to connect with their teachers and classmates anywhere and anytime [16]. Edmodo attracts more attention than other learning models, social networking with its features such as supporting work in the cooperative work of teachers and students in a safe environment. In addition to providing teaching material, Edmodo can also be used to provide assignments, quizzes, or assessments for students [17]. The effect of applying Edmodo in the learning process can be seen in this way; 
Flipped Classroom can improve students' ability to think creatively in the learning process [18].

The Edmodo website is similar to Facebook, but it is far more personal and secure because it allows teachers to create and manage accounts only for their students, who receive group codes and register in groups [15]. Nobody else can participate and spy. Edmodo is a simple M-learning tool that is used to present lesson content, which can be downloaded through all smartphone systems and provides a useful tool for students and teachers to interact online outside the classroom, anywhere and anytime [19]. The focus of this study is to find out whether there is an increase in student learning outcomes in the use of Edmodo-based Flipped Classroom learning models compared to conventional learning in economic subjects. By conducting an experiment research it will be known whether this Flipped Classroom learning model can improve student learning outcomes in Economics or not.

\section{Method}

\subsection{Research Design}

This research used a quantitative approach and the type of research was quasi-experimental. Quasi-experimental research involves two classes, namely the experimental class and the control class. The experimental class is the class that gets new treatment with what is being studied, while the control class is the class that gets the treatment as usual or according to the existing curriculum. Before getting treatment, both classes are balanced or almost balanced class. This research design used Pretest-Posttest Control Group Design. Pretest-posttest were conducted twice, namely before the experiment (pre-test) and after the experiment (post-test) with one group of subjects.

\subsection{Participants and Research Sites}

This research was conducted on all students of class $X$ Social Sciences in Senior High School at SMA Negeri 3 Sukoharjo which is located at Jendral Sudirman St. No.197, Jombor, Bendosari, Sukoharjo, Central Java, Indonesia, in the academic year of 2019/2020.

\subsection{Population}

In this study, the population is all students of class $\mathrm{X}$ Social Sciences totaling 175 students, population data of students per class can be seen in table 1 .

Table 1. Research Population

\begin{tabular}{|c|c|c|}
\hline No & Class & Number of Students \\
\hline 1 & X Social Sciences 1 & 35 \\
\hline 2 & X Social Sciences 2 & 35 \\
\hline 3 & X Social Sciences 3 & 35 \\
\hline 4 & X Social Sciences 4 & 35 \\
\hline 5 & X Social Sciences 5 & 35 \\
\hline & TOTAL & 175 \\
\hline
\end{tabular}

\subsection{Sample}

This study used a sample of 2 classes consisting of 72 students that were divided into a control class (X Social Sciences 3) and an experimental class (X Social Sciences 4).

\subsection{Sampling}

In this study, the researchers used probability sampling techniques. It is a sampling technique where all elements have the opportunity to be selected as a sample. Furthermore, the type of probability sampling used was simple random sampling, which is a simple random sampling method with the assumption that certain characteristics of the population are not considered in the study [20]

\subsection{Hypothesis}

H1: There is a difference in student learning outcomes from the use of flipped classroom learning models compared to conventional learning in the economic class $\mathrm{X}$ SMA Negeri 3 Sukoharjo.

\subsection{Technique of Data Analysis}

The data analysis technique used in this study was the pre-requisite analysis test, the data analysis test and the homogeneity test. The hypothesis testing used simple linear regression analysis test and independent sample t-test with a significance level of 5\%. This study was intended to determine the increase in student learning outcomes from the influence of Edmodo-based Flipped Classroom learning model. This research used quasi-experimental research because the researchers could not strictly control many factors through testing a statistical hypothesis. Statistical hypothesis is a statement or conjecture regarding one or more populations [21]. Experimental research is research to test an idea, practice or procedure to determine whether it influences the outcome or the dependent variable [20].

\section{Findings}

\subsection{Data of Student Learning Outcomes}

Research data from the pre-test and post-test assessment in two classes, namely the experimental class and the control class can be seen in table 2 .

Table 2 shows that the mean value of the experimental class pretest 52.29 is lower than the control class 62.00. But the mean value of the posttest results of the experimental class 70.00 is higher than the control class 62.43 . This shows that there is an increase in student learning outcomes from the use of the Flipped Classroom learning model Edmodo-based in comparison to conventional learning in economic subjects in high school. 
Table 2. Differences in Student Learning Outcomes Using Edmodo-based Flipped Classroom Learning Models and Conventional Learning

\begin{tabular}{|c|c|c|c|c|}
\hline \multirow{2}{*}{$\begin{array}{l}\text { Various } \\
\text { Source }\end{array}$} & \multicolumn{2}{|c|}{ Experimental Class } & \multicolumn{2}{c|}{ Control Class } \\
\cline { 2 - 5 } & Pre-test & Post-test & Pre-test & Post-test \\
\hline $\mathrm{N}$ & 35 & 35 & 35 & 35 \\
\hline Mean & 52.29 & 70.00 & 62.00 & 62.43 \\
\hline Mode & 55 & 65 & 50 & 50 \\
\hline Std. Deviation & 12.087 & 8.402 & 9.024 & 8.153 \\
\hline Minimum & 30 & 50 & 50 & 50 \\
\hline Maximum & 75 & 85 & 75 & 75 \\
\hline
\end{tabular}

Source: SPSS Data Management Results version 25.00

\subsection{Normality Test}

Normality test was carried out using Liliefors test technique or in the SPSS 25.00 program is better known as the Kolmograf-Smirnov. The criterion of the normality test is that the data are normally distributed with a significance probability value is $>0.05$. The summary of the normality test is as follows:

Table 3. Result of Normality Test

\begin{tabular}{|c|c|c|c|c|}
\hline Variables & $\mathrm{N}$ & $\begin{array}{c}\text { Sig. } \\
\text { Probability }\end{array}$ & $\begin{array}{c}\text { Error } \\
\text { Std. }(\alpha)\end{array}$ & Conclusion \\
\hline $\begin{array}{c}\text { Conventional } \\
\text { Pre-test }\end{array}$ & 35 & 0.148 & 0.05 & Normal \\
\hline $\begin{array}{c}\text { Conventional } \\
\text { Post-test }\end{array}$ & 35 & 0.063 & 0.05 & Normal \\
\hline $\begin{array}{c}\text { Experiment } \\
\text { Pre-test }\end{array}$ & 35 & 0.200 & 0.05 & Normal \\
\hline $\begin{array}{c}\text { Experiment } \\
\text { Post-test }\end{array}$ & 35 & 0.191 & 0.05 & Normal \\
\hline
\end{tabular}

Source: SPSS Data Management Results version 25.00
From the table above, it is known that the learning outcomes of each of the conventional class variables and the experimental class have a Significance Probability value of $>5 \%$ or 0.05 . So, from each variable derived from populations, it can be concluded that they are normally distributed.

\subsection{Homogeneity Test}

Homogeneity test of student learning outcomes can be seen in the attachment of the following table:

Table 4. Homogeneity Test Result

\begin{tabular}{|c|c|c|c|}
\hline Levene Statistic & df1 & df2 & Sig. \\
\hline 1,147 & 1 & 68 & 0.288 \\
\hline
\end{tabular}

Source: SPSS Data Management Results version 25.00

From the above table, it can be seen that from the testing with Lavene Statistics, a significance of 0.288 was obtained which is more than 0.05 . Thus, the research data above are homogeneous and show that the data between the conventional class and the experimental class have the same homogeneity or variance.

\subsection{Hypothesis Test}

The hypothesis test used in this study was the parametric statistical test, namely the Independent Sample t-test. It was used to find out how much the difference in student learning outcomes after being treated, both in the control class and in the experimental class. In the end, $\mathrm{H}_{0}$ will be accepted or rejected.

Table 5. Independent Sample T-test Result

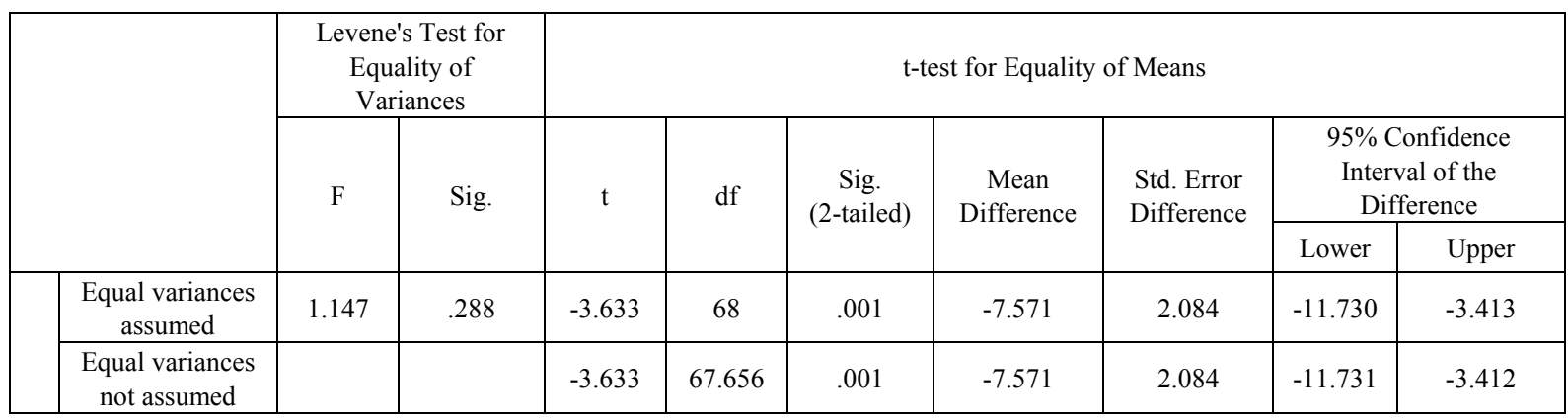

Source: SPSS Data Management Results version 25.00 
Based on the results of the t-test analysis, the t-count obtained was -3.633 , the negative t-count was not an error but was caused because the average value in the control class was lower than the average value of the experimental class. For decision making in the independent sample t-test through a comparison between the value of t-count with $\mathrm{t}$-table, then $\mathrm{t}$-count can be positive, which is 3.633 . $\mathrm{t}$-count 3.633 is greater than table 1.995 , and the significance value is $0.001<$ from 0.05 . From this result, it means that $\mathrm{H}_{0}$ is rejected and $\mathrm{H}_{1}$ the hypothesis is accepted. Then it can be concluded that there is a significant influence on the use of Edmodo-based Flipped Classroom learning models on economic learning outcomes of class X students of SMA Negeri 3 Sukoharjo.

\section{Discussion}

Based on the results of the analysis, it can be seen that there are differences in economic learning outcomes between using Edmodo-based Flipped Classroom learning model and using conventional learning model in class $\mathrm{X}$ IPS SMA Negeri 3 Sukoharjo. It is shown by the result of $\mathrm{t}$-count that is greater than $\mathrm{t}$-table $(3.633>1.995)$ and the significance value of 0.001 is smaller than 0.05 .

It can also be seen from the average student learning outcomes through post-test that are higher in the experimental class than the results of the post-test in the control class. The average post-test in the experimental class was 70.00 , while the average post-test in the control class was 62.43. From these results, it can be concluded that the use of Edmodo-based Flipped Classroom learning models can provide a significant influence on economic learning outcomes in the experimental class. The results of this study are in accordance with previous research which states that there is a significant influence on the improvement of student learning outcomes in learning with the Flipped Classroom model [22].

Increasing critical and creative thinking skills can be done by learning videos before entering the classroom. The use of Edmodo-based Flipped Classroom learning strategy is a learning model that utilizes technological developments in the 21 st century. This learning model guides students more effectively and actively in the learning process. The previous research stated that the Flipped Classroom learning model was more effective in learning because there was an increase in student test results [23]. It also helped students not to fall behind in subject matter if they were unable to attend the class.

Giving material in this learning model can be done through a video that has been uploaded by the teacher through Edmodo. The learning model aims to train the independence of students in self-study at home and train students to focus on paying attention to the instructional video that has been given by the teacher. After studying the instructional video at home, students are asked to discuss with friends or deepen the material that has been learned but do not really understand while they are in the classroom. In this learning model, the teacher only acts as a facilitator. After that, students are given questions to find out students' knowledge after using Edmodo-based Flipped Classroom learning model and the result is the students who have used the learning model are able to get high enough learning outcomes. This is consistent with the previous research which showed higher test scores for students who used the Flipped Classroom approach compared to students who learned using traditional methods [24]. Previous studies also showed similar results for English language lessons [25]. So, the Edmodo-based Flipped Classroom learning model can be used to improve student learning outcomes.

Although it has several obstacles in its application, these obstacles can be handled properly. The obstacle that researchers faced was students did not know how to operate the Edmodo application so they did not know how to join online classes. There were also students who have joined Edmodo but did not want to see the learning videos. Previous research stated that initially, the use of technology in the classroom for the learning process was quite difficult for the students [26]. During the class meetings, there were still many students who looked shy and afraid to present what they have understood so that learning in the classroom became less effective.

There are some efforts to overcome these problems, such as teachers must be able to utilize technology in creating new variations of learning models and they are always asked to provide direction and motivation to students. In addition, students are expected to be more active during the learning process. According to the results of testing the hypotheses and descriptive description that has been described, Edmodo-based Flipped Classroom learning model has a positive impact on student economic learning outcomes. This can be seen from the post-test scores in Edmodo-based Flipped Classroom learning that are better than the post-test scores in conventional learning.

\section{Conclusions}

The results of the study suggest that economic learning using Edmodo-based Flipped Classroom learning models can more effectively improve student learning outcomes compared to learning with conventional systems. Flipped Classroom is proven to be one of the good learning model in teaching and learning because it can train students to understand the material at home before entering the class, so when they are in the classroom students can focus more on their difficulties in understanding the material or their ability to solve problems related to the material. Our study suggests that the model of Edmodo-based Flipped Classroom learning can improve students' learning outcomes because their learning processes become more effective. Students can repeat the learning videos that have 
been given by the teacher until they really understand.

The model of Edmodo-based Flipped Classroom learning also makes teaching and learning processes not monotonous because students do not only listen to explanations of material from the teacher. We recommend some suggestions to overcome the drawbacks of this learning model. First, the students should be active in taking online classes because to learn the learning video first before the class starts because students who are not active in taking online classes can have low learning outcomes. Second, teachers should make sure that the students do not open other irrelevant applications such as games or other social media instead of opening Edmodo application, for example by blocking the irrelevant applications. So, in future, the use of Edmodo-based Flipped Classroom learning model still requires a lot of supports, such as the availability of teachers in mastering technology, the teacher's deeper understanding of Flipped Classroom, the supporting tools students have, and so on.

\section{REFERENCES}

[1] Crews, T., \& Butterfield, J. B. (2014). Data for Flipped Classroom Design: Using Student Feedback to Identify the Best Components from Online and Face-to-Face Classes. Higher Education Studies, 4(3), 38-47. https://doi.org/10.5539/hes.v4n3p38

[2] APJII. (2017). Infografis Penetrasi \& Perilaku Pengguna Internet Indonesia. In Teknopreuner.

[3] Susilo, A. (2015). Penerapan Strategi Pembelajaran Teams Games Tournament Dengan Media Permainan Monopoli Untuk Meningkatkan Keaktifan Dalam Pembelajaran Akuntansi Pada Siswa SMA. Prosiding Seminar Nasional Pendidikan Akuntansi Dan Keuangan, 2, 208-218.

[4] Bergmann, \& Sams, A. (2012). Flip Your Classroom: Reach Every Student in Every Class Every Day. In G. Lynda \& W. Tina (Eds.), International Society for Technology in Education (First Edit). Courtney Burkholder.

[5] Bergmann, J., Overmyer, J., \& Wilie, B. (2013). The Flipped Class: Myths vs. Reality. Thedailyriff.Com. http://www.thedailyriff.com/articles/the-flipped-class-conv ersation-689.php

[6] Mok, H. N. (2014). Teaching tip: The flipped classroom Teaching Tip : Journal of Information Systems Education, 25(1), 7-11.

[7] Tucker, B. (2012). The Flipped Classroom Online instruction at home frees class time for learning. Innovations in Flipping the Language Classroom: Theories and Practices, 1-9. https://doi.org/10.1007/978-981-10-6968-0_1

[8] Ultanir, E. (2012). Citrus juice modulates antioxidant enzymes and lipid profiles in orchidectomized rats. Journal of Medicinal Food, 9(3), 422-426. https://doi.org/10.1089/j mf.2006.9.422

[9] Harris, C. J. (2016). Flipping the undergraduate economics classroom: Using online videos to enhance teaching and learning. Southern Economic Journal, 83(1), 321-331. https://doi.org/10.1002/soej.12128

[10] Bishop, J., \& Verleger, M. (2013). The Flipped Classroom: A Survey of the Research. Proceedings - Frontiers in Education Conference, FIE, 161-163.https://doi.org/10.110 9/FIE.2013.6684807

[11] Hsieh, S. C., Jun, S., Wu, Vivian, W. C., \& Marek, M. (2017). Using the flipped classroom to enhance EFL learning. Computer Assisted Language Learning, 30(1-2), 1-21. https://doi.org/10.1080/09588221.2015.1111910

[12] Hao, Y. (2016). Exploring undergraduates' perspectives and flipped learning readiness in their flipped classrooms. Computers in Human Behavior, 59, 82-92. https://doi.org/10.1016/j.chb.2016.01.032

[13] Milman, N. B. (2012). The Flipped Classroom Strategy: What is it and how can it be used? Distance Learning, 11(4), 9-11.

[14] Johnson, G. B. (2013). Student perceptions of the flipped classroom. University of British Columbia. 1-95. https://doi.org/10.14288/1.0073641

[15] Borg, N., O’hara, J., \& Hutter, C. (2012). About Edmodo. $1-4$ https://www.edmodo.com/images/rttd/Edmodo_RTTD_Ov erview.pdf

[16] Balasubramanian, K., Jaykumar, V., \& Fukey, L. N. (2014) A Study on Student Preference towards the Use of Edmodo as a Learning Platform to Create Responsible Learning Environment. Procedia - Social and Behavioral Sciences, 144, 416-422. https://doi.org/10.1016/j.sbspro.2014.07.311

[17] Giang, T. N., \& Minh, N. Van. (2014). Edmodo - A new and effective blended learning solution. Edmodo - a New and Effective Blended Learning Solution, June, 1-6. http://14.161.11.88/InternationalConference2014/Materials/ NgocGiang_VanMinh.pdf

[18] Widyaningrum, H. K., Hasanudin, C., Fitrianingsih, A., Novianti, D. E., Saddhono, K., \& Supratmi, N. (2020). The use of Edmodo apps in flipped classroom learning. How is the students' creative thinking ability? Ingenierie Des Systemes d'Information, 25(1), 69-74. https://doi.org/10.18 280/isi.250109

[19] Hourdequin, P. (2014). Edmodo: A Simple Tool for Blended Learning. February, 31-35. https://jalt-publications.org/tlt/d epartments/tlt-wired/articles/3547-edmodo-simple-tool-blen ded-learning

[20] Creswell, J. W. (2012). Research Design: Pendekatan Kualitatif, Kuantitatif, dan Mixed. Pustaka Pelajar.

[21] Harsono. (2016). Etnografi Pendidikan: Suatu Desain Penelitian Kualitatif. Gumpang Agung III.

[22] Suryacitra, G. E. (2018). Efektivitas Penerapan Model Pembelajaran Flipped Classroom Di Kelas X MIPA SMA N 1 Karanganom Tahun Ajaran 2017/2018 Pada Materi Vektor. https://repository.usd.ac.id/31297/2/141414051_full.pdf

[23] Waznah, S., \& Latif, A. (2017). Implementing the Flipped Classroom Model in the Teaching of History. 11, 374-381. https://doi.org/10.11591/edulearn.v11i4.6390

[24] Love, B., Hodge, A., Grandgenett, N., \& Swift, A. W. (2014). 
Student learning and perceptions in a flipped linear algebra course. International Journal of Mathematical Education in Science and Technology, 45(3), 317-324. https://doi.org/10.1080/0020739X.2013.822582

[25] Hung, H. T. (2015). Flipping the classroom for English language learners to foster active learning. Computer Assisted Language Learning, 28(1) https://doi.org/10.1080/09588221.2014.967701

[26] Gitonga, R., Muuro, M., \& Onyango, G. (2016). Technology integration in the classroom: A case of students experiences in using Edmodo to support learning in a blended classroom in a Kenyan University. 2016 IST-Africa Conference, IST-Africa 2016, 1-8. https://doi.org/10.1109/ISTAFRICA. 2016.7530591 